\title{
Change in Ability of Agrobacterium to Produce Water-soluble and Water-insoluble $\beta$-Glucans
}

\author{
By M. HISAMATSU, I. OTT,*A. AMEMURA AND T. HARADA \\ The Institute of Scientific and Industrial Research, \\ Osaka University, Suita, Osaka, Japan \\ I. NAKANISHI AND K. KIMURA \\ Takeda Chemical Industries Ltd, Takasago Plant, \\ Takasago, Hyogo, Japan
}

(Received 28 June 1977; revised 3 August 1977)

\begin{abstract}
Four of nine stock cultures of Agrobacterium tested formed mixtures of two types of colonies, which were distinguished on plates of aniline blue medium because of the difference in their production of two exocellular polysaccharides. The ability of organisms from the white colonies of strain IFOI 2665 to produce large amounts of water-soluble polysaccharide was unstable; when kept on nutrient agar slants or in inorganic salt solution the bacteria mutated spontaneously to yield blue colonies producing large amounts of curdlan-type polysaccharide instead.
\end{abstract}

\section{INTRODUCTION}

Curdlan is a $\beta$-glucan which is composed entirely of $(\mathrm{I} \rightarrow 3)-\beta$-glucosidic linkages and it forms a firm, resilient gel when heated in aqueous suspension (Maeda et al., I967; Harada, Misaki \& Saito, 1968a; Saito, Misaki \& Harada, 1968). This polymer was first found to be formed in high yield by a mutant strain (IOC3K) (Harada et al., 1966) of Alcaligenes faecalis var. myxogenes $\mathrm{roc}_{3}$ which produces a water-soluble, acidic polysaccharide (succinoglucan) (Harada, 1965). Recently, we have investigated the distribution of curdlantype polysaccharide in micro-organisms by using the aniline blue method in which organisms forming curdlan-type polysaccharide are detected as blue colonies on aniline blue plates. In this way, some strains of Agrobacterium were found to produce curdlan-type polysaccharide with water-soluble polysaccharide (Nakanishi et al., 1976). In addition, some stock cultures of Agrobacterium formed mixtures of blue and white colonies on aniline blue plates; these variant forms developed spontaneously under normal conditions for maintenance of bacteria on agar slants. The present paper describes studies on the instability of polysaccharide production in Agrobacterium.

\section{METHODS}

Strains. Seven strains of Agrobacterium radiobacter, one strain of Agrobacterium rhizogenes and one strain of Agrobacterium tumefaciens (see Table I) were obtained from the Institute of Fermentation, Oaska.

Media. The stock culture medium (PY medium) contained $(\%, w / v)$ : peptone (Takeda), I; yeast extract, $0.5 ; \mathrm{NaCl}, 0.5 ; \mathrm{pH} 7 \cdot 2$. PY agar contained, in addition, $2 \%$ agar. AB medium [containing $(\%, \mathrm{w} / \mathrm{v})$ : glucose, I ; yeast extract, 0.5 ; aniline blue, $0.005 ;$ agar, $2 ; \mathrm{pH} 7 \cdot 2$ ] was used to detect colonies forming curdlan, because aniline blue combines specifically with curdlan (Nakanishi et al., 1974). The synthetic medium (S

* Present address: Research Institute for Pharmaceutical Chemistry, I045 Budapest, Hungary. 
Table I. Formation of water-soluble and water-insoluble polysaccharides by strains isolated from various stock cultures of Agrobacterium

\begin{tabular}{|c|c|c|c|c|c|}
\hline \multirow[b]{2}{*}{ Strain } & & \multirow[b]{2}{*}{$\begin{array}{l}\text { Appearance } \\
\text { on AB plates }\end{array}$} & \multicolumn{2}{|c|}{$\begin{array}{l}\text { Exocellular polysaccharide } \\
\text { produced }\left[\mathrm{mg}(100 \mathrm{ml})^{-1}\right]\end{array}$} & \multirow{2}{*}{$\begin{array}{c}\text { Wt of organisms } \\
\text { formed } \\
{\left[\mathrm{mg} \mathrm{dry} \mathrm{wt}(\mathrm{IOO} \mathrm{ml})^{-1}\right]}\end{array}$} \\
\hline & & & $\begin{array}{l}\text { Water- } \\
\text { soluble }\end{array}$ & $\begin{array}{l}\text { Water- } \\
\text { insoluble }\end{array}$ & \\
\hline \multicolumn{2}{|c|}{ A. radiobacter IFOI 2607} & Blue & 70 & 500 & 170 \\
\hline & IFOI 2664 & White & 270 & 0 & I 55 \\
\hline & IFOI 2665 & Blue and white & 670 & 15 & 100 \\
\hline & IFOI 3127 & Blue and white & 400 & 80 & 120 \\
\hline & IFOI 3256 & Blue (two types) & 130 & I 20 & 150 \\
\hline & IFOI 3532 & White & 300 & 0 & 100 \\
\hline & IFOI 3533 & White & 1200 & 0 & 80 \\
\hline A. rhizogenes & IFOI 3259 & Blue (two types) & 120 & 480 & 160 \\
\hline A. tumefacien. & $\mathrm{IFO}_{305} 8$ & White & I80 & 0 & 60 \\
\hline
\end{tabular}

medium) described previously (Amemura \& Harada, 1971) was used to examine polysaccharide production by the organisms.

Culture conditions for polysaccharide production. S medium $(95 \mathrm{ml})$ in $500 \mathrm{ml}$ conical flasks was inoculated with a seed culture $(5 \mathrm{ml})$ which had been grown in the same medium. The culture was shaken reciprocally at 120 strokes $\min ^{-1}$ at $30^{\circ} \mathrm{C}$ for 5 days.

Determination of water-soluble and water-insoluble polysaccharides. Amounts of water-soluble and waterinsoluble polysaccharides were assayed by the method of Harada et al. (1968b).

\section{RESULTS AND DISCUSSION}

Coexistence of different types of organisms in stock cultures of Agrobacterium

The amounts of water-soluble and water-insoluble polysaccharides produced by nine strains of Agrobacterium were measured (Table I). Organisms from white colonies of strains I2665 and 13127 and those obtained from slimy blue colonies of strains 13256 and I3259 were selected for examination, because white colonies or slimy blue colonies may be the parent strains, as shown for Alcaligenes faecalis var. myxogenes (Hisamatsu et al., 1976). Stock cultures of the other five strains were used directly. Organisms giving only blue colonies produced considerable amounts of water-insoluble polysaccharide; those giving only white colonies produced only water-soluble polysaccharide. Organisms giving white colonies, selected from cultures growing as a mixture of white and blue colonies, produced considerable amounts of water-soluble polysaccharide, whereas organisms giving slimy blue colonies, selected from cultures in which two types of blue colonies were present, produced both water-soluble and water-insoluble polysaccharides. These results confirm that water-insoluble polysaccharide (curdlan-type polysaccharide) forms a complex with aniline blue, as previously reported (Nakanishi et al., 1974).

Agrobacterium radiobacter IFOI 2665 was selected for the following experiments, because it formed very distinct blue and white colonies. Blue and white colonies were picked at random from a plate of the organism and the pure cultures derived from them were spread on AB medium plates (Fig. I $a, c$ and $d$ ). The strain $12665 \mathrm{~W}$ obtained from a white colony was unstable yielding blue colonies (Fig. $\mathrm{x} b$ ), whereas strains I2665B I and I2665B2 obtained from blue colonies were stable for up to 60 days on PY agar slants. The organism giving white colonies may be the parent strain and it may mutate to organisms giving blue colonies. The production of polysaccharide by these organisms was measured. Strain I 2665W produced large amounts $\left(6.7 \mathrm{mg} \mathrm{ml}^{-1}\right)$ of water-soluble polysaccharide but only small amounts of water-insoluble polysaccharide $\left(0.15 \mathrm{mg} \mathrm{ml}^{-1}\right)$, while strains I2665B I and $\mathrm{I}_{2665 \mathrm{~B} 2}$ produced large amounts of water-insoluble polysaccharide $\left(9.9\right.$ and $5.6 \mathrm{mg} \mathrm{ml}^{-1}$, 


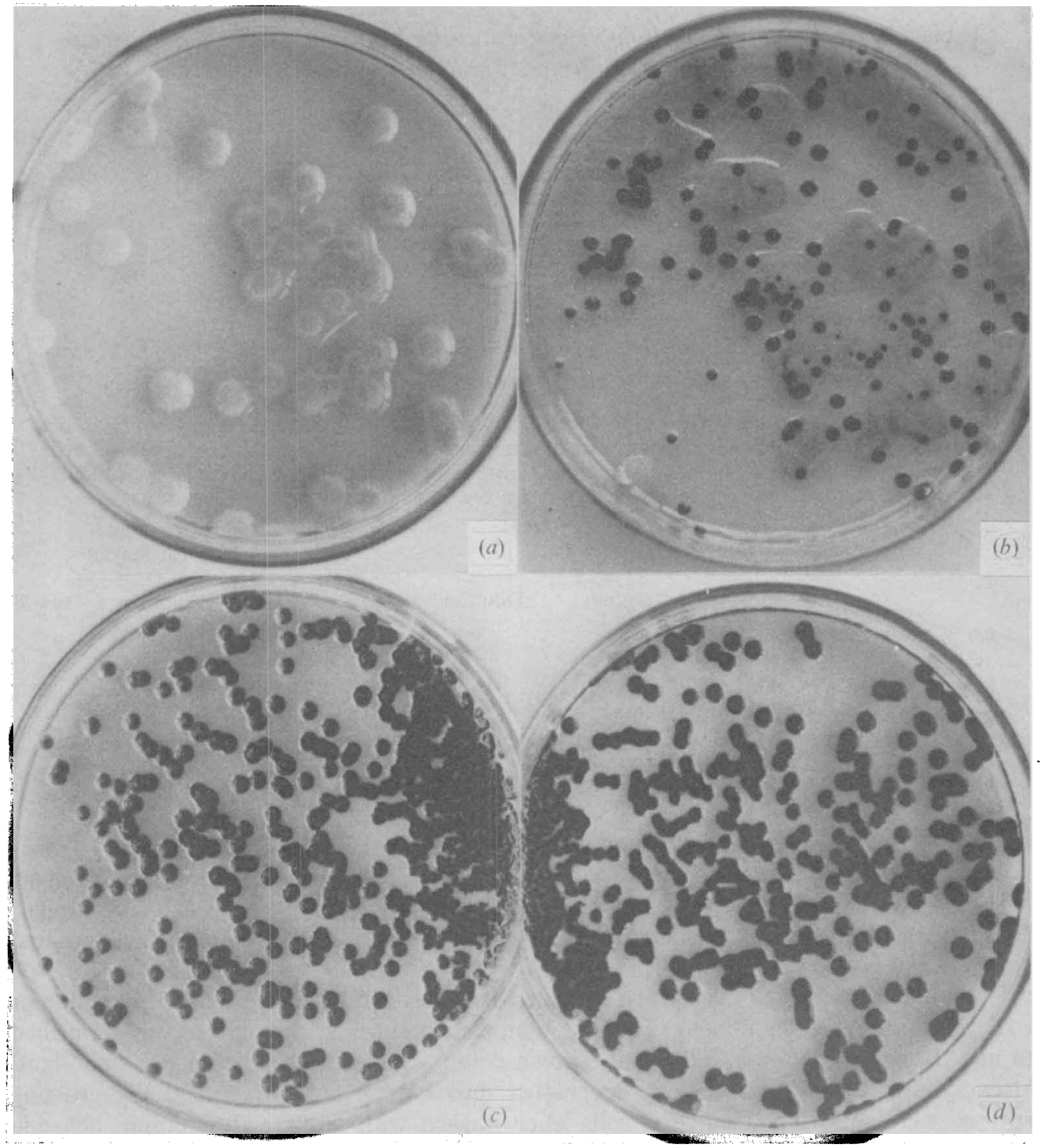

Fig. 1. Colonies of Agrobacterium radiobacter after growth at $30^{\circ} \mathrm{C}$ for 5 days on AB medium: (a) strain $12665 \mathrm{~W}$ (fresh pure culture); (b) strain I2665W (culture incubated for 60 days after purification); (c) strain 12665BI (fresh pure culture); (d) strain I2665B2 (fresh pure culture).

respectively) with small amounts $\left(0.87\right.$ and $\left.0.89 \mathrm{mg} \mathrm{ml}^{-1}\right)$ of water-soluble polysaccharide. The colonies of strains I 2665B I and I 2665B2 were slightly different in shape.

\section{Spontaneous mutation of ability to produce polysaccharide}

Colonies producing curdlan-type polysaccharide are stained well with aniline blue, whereas those producing only succinoglucan are not (Nakanishi et al., 1976). The insoluble polysaccharide of $A$. radiobacter is a curdlan-type polysaccharide (Nakanishi et al., 1974) and the soluble polysaccharide was similar to succinoglucan, as described below.

Strain 12665W was maintained on PY agar slants for 60 days. Spontaneous mutant strains I 2665WbI, 2, 3 and 4, which were stained blue with aniline blue, were then isolated and tested for production of water-soluble and water-insoluble polysaccharides (Table 2). 
Table 2. Formation of water-soluble and water-insoluble polysaccharides by strains derived spontaneously from $A$. radiobacter strain $\mathrm{I} 2665 \mathrm{~W}$

$\begin{array}{lcc}\begin{array}{c}\text { Mutant } \\ \text { strain }\end{array} & \begin{array}{c}\text { Exocellular polysaccharide produced } \\ {\left[\mathrm{mg}(\mathrm{I00} \mathrm{ml})^{-1}\right]}\end{array} \\ \text { I2665Wbi } & \text { Water-soluble } & \text { Water-insoluble } \\ \text { I2665Wb2 } & 10 & 1100 \\ \text { I2665Wb3 } & 84 & 600 \\ \text { I2665Wb4 } & 72 & 330 \\ & 0 & 190\end{array}$

Table 3. Effect of incubation time in sodium chloride solution or phosphate buffer on the appearance of blue colonies on aniline blue plates

Agrobacterium radiobacter strain $12665 \mathrm{~W}$ was incubated at $30^{\circ} \mathrm{C}$ in sodium chloride solution or phosphate buffer. Periodically samples were removed and $0.1 \mathrm{ml}$ portions of appropriately diluted suspension were spread on aniline blue plates. Numbers of blue and white colonies were counted after 5 days at $30^{\circ} \mathrm{C}$. Values are the averages from two experiments.

\begin{tabular}{|c|c|c|c|c|c|c|c|c|c|c|}
\hline & & & & $\begin{array}{l}\mathrm{No} \\
\text { afte }\end{array}$ & $\begin{array}{l}\text { of } \\
\text { incl }\end{array}$ & $\begin{array}{l}\text { color } \\
\text { bati }\end{array}$ & $\begin{array}{l}\text { ies } \\
\text { on } \mathrm{f}\end{array}$ & $\begin{array}{l}\text { er } p \\
\text { pr }(d\end{array}$ & $\begin{array}{l}\text { late } \\
\text { ays) }\end{array}$ & \\
\hline & $\begin{array}{l}\text { Iype or } \\
\text { colony }\end{array}$ & Dilution & 0 & I & 2 & 3 & 4 & 6 & 8 & IO \\
\hline $0.9 \% \mathrm{NaCl}$ solution & Blue & I & 0 & 0 & $\mathbf{I}$ & I & 14 & 80 & 102 & 9 \\
\hline & White & $10^{5}$ & & & & & & & 8 & I \\
\hline & & $10^{6}$ & 132 & IOI & 93 & 90 & 62 & $2 \mathrm{I}$ & & \\
\hline $0.02 \mathrm{M}$-phosphate buffer pH 6.0 & Blue & $\mathbf{I}$ & o & $\mathbf{I}$ & 28 & $3 \mathbf{I}$ & 105 & & & \\
\hline & & Io & & & & & 9 & 212 & 94 & 0 \\
\hline & White & $10^{5}$ & & & & & & & 297 & 2 \\
\hline & & $10^{6}$ & 127 & 123 & 105 & 94 & 90 & 82 & $3 \mathrm{I}$ & o \\
\hline
\end{tabular}

The ability of these strains to produce the polysaccharides was stable during 60 days incubation on PY agar slants. The production of the two polysaccharides by strains I 2665B I and I2665B2 (described above), and by strains $\mathrm{I}_{2} 665 \mathrm{Wb2}$ and I2665Wb3 was similar. Thus, strains I2665B I and I2665B2 in the stock culture of IFOI $2665 \mathrm{seem}$ to have mutated from a strain giving white colonies.

The mutation occurred even when a suspension of strain $12665 \mathrm{~W}$ was kept in saline or $0.02 \mathrm{M}$-phosphate buffer $\mathrm{pH} 6.0$ (Table 3). Before experiments, the culture was repurified on an AB medium plate and a freshly grown colony was transferred to a PY agar slant. After 2 days, the organisms were inoculated into PY medium. Exponentially growing cultures were centrifuged and the cells were washed with $0.9 \%(w / v)$ sodium chloride solution and resuspended in the same solution. Portions of this suspension ( $\mathrm{I} \mathrm{ml}$, containing about $\mathrm{I} \cdot 3 \times \mathrm{IO}^{11}$ bacteria) were inoculated into $100 \mathrm{ml}$ of $0.9 \%$ sodium chloride solution or $0.02 \mathrm{M}$-phosphate buffer $\mathrm{pH} 6.0$ in $500 \mathrm{ml}$ conical flasks and incubated at $30{ }^{\circ} \mathrm{C}$ with shaking. Samples were removed periodically, and $0.1 \mathrm{ml}$ portions of appropriately diluted suspension were spread on $\mathrm{AB}$ medium plates. After 5 days at $30^{\circ} \mathrm{C}$, the numbers of blue and white colonies which had developed were counted. Strain I2665W formed white colonies which were stained slightly with the dye. It was difficult to count the blue colonies when the parental white colonies predominated on the plate, but good reproducibility of determinations was achieved when the ratio of blue to white colonies was higher than $\mathrm{I}$ in $5 \times 10^{8}$. The pure fresh culture of strain $\mathrm{I} 2665 \mathrm{~W}$ used gave a ratio of less than $\mathrm{I}$ in $5 \times 10^{8}$. When incubated in saline, the number of blue colonies increased significantly on day 4 and continued to increase until day 8 , but decreased on day Io. In contrast, the number of white colonies decreased steadily throughout the incubation, probably due to autolysis. On day 8 of incubation, about $0.6 \%$ of the bacteria were viable, and the ratio of blue colonies to white colonies was about $\mathrm{I}$ in $8 \times 10^{3}$. When incubated in phosphate 
buffer, the number of blue colonies was at its maximum on day 6 of incubation, the ratio of blue colonies to white colonies being about $\mathrm{I}$ in $4 \times 10^{4}$. On day 10 , when most of the bacteria had died, the ratio was about $\mathrm{I}$ in $2 \times 10^{4}$. This change is similar to the change seen in the production of succinoglucan and curdlan by Alcaligenes faecalis var. myxogenes (Hisamatsu et al., 1976). The mechanism of spontaneous mutation is unknown.

Recently, we showed (Hisamatsu et al., I977) that all the water-soluble polysaccharides from Agrobacterium have succinic acid as an acidic component and $\beta$-glucan as a moiety of the polysaccharide which is hydrolysed to a polymer with a degree of polymerization of about 12 (Hisamatsu et al., 1977) by a specific $\beta$-glucanase, succinoglucan depolymerase from Flavobacterium м64 (Amemura, Moori \& Harada, 1974). They are similar to the succinoglucan of Alcaligenes faecalis var. myxogenes Ioc3 (Harada, 1965; Misaki et al., I969; Saito, Misaki \& Harada, 1970). It is interesting that spontaneous mutation in the ability to produce water-soluble $\beta$-glucan (acidic $\beta$-glucan containing succinic acid) and water-insoluble $\beta$-glucan (curdlan-type polysaccharide) occurs frequently in both genera. It has been generally thought that isolates from different sources from gall-type growths, or non-infective variants of Agrobacterium, are readily confused with members of the genus Alcaligenes (Allen \& Holding, 1974). There seem to be no definitive characteristics for classification of organisms in the genera Agrobacterium and Alcaligenes other than their abilities to form galls. Thus, the spontaneous mutation described here may be useful in studies on strains of Alcaligenes and Agrobacterium.

This work was supported by a grant 256077 to T. Harada from the Ministry of Education, Science and Culture of Japan.

\section{REFERENCES}

Allen, O. N. \& Holding, A. J. (1974). Genus II. Agrobacterium. In Bergey's Manual of Determinative Bacteriology, 8th edn, p. 264. Edited by R. E. Buchanan and N. E. Gibbons. Baltimore: Williams \& Wilkins.

amemura, A. \& Harada, T. (1971). Production of succinoglucan by Alcaligenes faecalis var. myxogenes growing in defined medium and in nongrowing cell suspensions. Journal of Fermentation Technology 49, 559-564.

Amemura, A., Moori, K. \& Harada, T. (1974). Purification and properties of a specific, inducible $\beta$-glucanase, succinoglucan depolymerase from Flavobacterium. Biochimica et biophysica acta 334, 398-409.

HARADA, T. (1965). Succinoglucan IOC3: a new acidic polysaccharide of Alcaligenes faecalis var. myxogenes. Archives of Biochemistry and Biophysics 112, 65-69.

harada, T., Masada, M., Fujimori, K. \& Maeda, I. (1966). Production of a firm, resilient gelforming polysaccharide by a mutant of Alcaligenes faecalis var. myxogenes Ioc3. Agricultural and Biological Chemistry 30, 196-198.

harada, T., Misaki, A. \& Saito, H. (1968a). Curdlan: a bacterial gel-forming $\beta$-1,3-glucan. Archives of Biochemistry and Biophysics 124, 292-298.

harada, T., Amemura, A., Satto, H., Kanamuru, S. \& MisAKI, A. $(1968 b)$. Formation of succinoglucan and curdlan by parent and mutant strains of Alcaligenes faecalis var. myxogenes IOC 3 . Journal of Fermentation Technology 46, 679-684.

Hisamatsu, M., Amemura, A., Harada, T., NakaNISH, I. \& KIMURA, K. (1976). Stability of succinoglucan and curdlan production of Alcaligenes faecalis var. myxogenes IOc3. Abstracts of the

Annual Meeting of Agricultural Chemical Society of Japan, p. 299.

Hisamatsu, M., Sano, K., Abe, J., Amemura, A. \& HARADA, T. (1977). Occurrence of succinic acid in water-soluble polysaccharide produced by strains of Agrobacterium. Abstracts of the Annual Meeting of Agricultural Chemical Society of Japan, p. 57 .

Maeda, I., Saito, H., Masada, M., Misaki, A. \& HaRADA, T. (1967). Properties of gels formed by heat treatment of curdlan, a bacterial $\beta-1,3-$ glucan. Agricultural and Biological Chemistry 3r, II84-I I 88 .

Misaki, A., Saito, H., Ito, T. \& Harada, T. (1969). Structure of succinoglucan. An exocellular acidic polysaccharide of Alcaligenes faecalis var. myxogenes. Biochemistry 8, 4645-4650.

NAKANISHI, K., KimURA, K., KuSUI, S. \& YamaZAKI, E. (1974). Complex formation of gelforming bacterial $(\mathrm{I} \rightarrow 3)-\beta$-D-glucan (curdlantype polysaccharides) with dyes in aqueous solution. Carbohydrate Research 32, 47-52.

Nakanishi, I., Kimura, K., Suzuki, T., Ishikawa, M., BanNo, I., Sakane, T. \& Harada, T. (1976). Demonstration of curdlan-type polysaccharide and some other $\beta$-I,3-glucans in microorganisms with aniline blue. Journal of General and Applied Microbiology 22, I-I I.

Saito, M., Misaki, A. \& Harada, T. (I968). A comparison of the structure of curdlan and pachyman. Agricultural and Biological Chemistry 32, I26I-1 269.

Saito, H., Misaki, A. \& Harada, T. (1970). Structure of succinoglucan: fragmentation by partial acid hydrolysis. Agricultural and Biological Chemistry 34, I683-1689. 